\title{
Mesangial Cells Initiate Compensatory Tubular Cell Hypertrophy
}

\author{
$\begin{array}{llll}\text { I. Sinuani } & \text { I. Beberashvili } & \text { Z. Averbukh } & \text { M. Cohn } \\ & \text { I. Gitelman } & \\ & \text { b }\end{array}$ \\ J. Weissgarten ${ }^{\text {a }}$ \\ ${ }^{a}$ Nephrology Division, Assaf Harofeh Medical Center Affiliated to the Sackler Faculty of Medicine, \\ Tel Aviv University, Zerifin, and ${ }^{\text {b}}$ Department of Molecular Genetics of Development, Ben Gurion University, \\ Beer Sheva, Israel
}

\section{Key Words}

Unilateral nephrectomy • Mesangial cells $\cdot$ Growth factors • Tubular cell $\cdot$ Hypertrophy $\cdot$ Compensatory growth • Cell cycle

\begin{abstract}
Unilateral nephrectomy results in compensatory renal growth, in which both the size and the functional capacity of the remaining kidney are increased. The functional adaptation to the removal of the contralateral kidney consists mostly of an increase in the glomerular filtration rate of the remaining kidney, and hypertrophy of cells comprising the nephron, mainly of the proximal tubular cells. Although the phenomenon of single kidney hypertrophy has been known for the past thousand years and despite intensive research over the past century, the mechanism of this process still remains unclear. The present article reviews the role of mesangial cells in compensatory renal hypertrophy.
\end{abstract}

Copyright $\odot 2010$ S. Karger AG, Basel

\section{Introduction}

Compensatory renal growth initiated by unilateral nephrectomy is a multistep adaptive process that leads to increased function of the remaining kidney. Within several weeks after unilateral nephrectomy, the remaining kidney increases in size, and begins to compensate for its missing partner. It is known that mammals having only a single kidney do not suffer from renal insufficiency. This phenomenon has been known and has fascinated physicians for more than two thousand years. Aristotle (384-322 BC) was probably the first to report that animals born with a single kidney can develop normally; he concluded that the full complement of renal tissue is not necessary for a normal animal to survive [1]. Later, Vesalius (1514-1564) found that single functional kidneys in humans were sufficient for normal life [2].

Although the phenomenon of single kidney compensatory growth is known, and despite extensive research over the past century, the mechanism responsible for this process is not yet clear.

Immediately after removal of the contralateral kidney, the remaining kidney is subject to a state of hyperfiltration $[3,4]$. The changes in glomerular hemodynamics activate a sequence of growth events leading to compensatory growth of the remaining kidney.

\section{KARGER \\ Fax +41613061234 E-Mail karger@karger.ch} www.karger.com
Dr. Inna Sinuani, PhD

Nephrology Division

Assaf Harofeh Medical Center

IL-70300 Zerifin (Israel)

Tel. +972 8977 9383, Fax +972 8977 9705, E-Mail sinuanii@ asaf.health.gov.il 
Mesangial cells play a crucial role in glomerular functioning under both normal physiologic and pathologic conditions. Mesangial cells provide structural support for the glomerular capillary loops, and modulate glomerular capillary flow and ultrafiltration surface, thereby regulating the glomerular filtration rate [5]. In addition, the mesangium serves as a source and target of vasoactive hormones, growth factors, cytokines, and extracellular matrix proteins, and thus contributes to the pathophysiology of the variety of glomerular diseases [6]. The present review will attempt to summarize the role of mesangial cells in compensatory growth of the remaining kidney.

\section{Cellular and Molecular Events Underlying Compensatory Renal Growth}

During the first hour after nephrectomy, significantly increased expression of both positive growth control factors, including c-jun, cyclin C, cyclin E, erg-1, as well as negative growth control factors, such as WT-1, p53, Rb, and gas-2, is observed in the remaining kidney tissues. mRNA levels of extracellular matrix proteins such as fibronectin and collagen I, and heat shock genes hsp70, hsp86, hsp90 $\beta$ are also increased [7]. Thus, unilateral nephrectomy induces stimuli that promote compensatory renal growth, in parallel with signals that suppress this process.

In adult organisms, compensatory growth of the remaining kidney occurs mainly through the hypertrophy of tubular cells. Hypertrophied cells increase their volume due to increased RNA and protein synthesis, without DNA replication. Studies have shown that tubular cell hypertrophy following unilateral nephrectomy is mediated by a cell cycle-dependent mechanism. This involves entry of cells into the $G_{1}$ phase of the cell cycle, initiating $\mathrm{G}_{1}$-related events, followed by arrest of cell cycle progression prior to the $\mathrm{G}_{1} / \mathrm{S}$ checkpoint. Retinoblastoma protein $(\mathrm{pRb})$, which is known as a suppressor of E2F transcription factor, plays a key role in the progression across the $\mathrm{G}_{1} / \mathrm{S}$ interphase. In the quiescent, dephosphorylated state, $\mathrm{pRb}$ forms complexes with E2F and inhibits E2F activity. Activation of $\mathrm{pRb}$ proteins lead to separation of E2F from its inhibitory unit, enabling the transcription of S-phase genes [8-10]. Activation of $\mathrm{pRb}$ requires its serial phosphorylation first by cyclin D/CDK4/6, and then by cyclin E/CDK2 complexes. Such stepwise pRb phosphorylation is necessary because cyclin $\mathrm{D}$ cannot fully phosphorylate $\mathrm{pRb}$, while cyclin E cannot act on the unphosphorylated form of $\mathrm{pRb}$ [11-14]. Thus, progression through $\mathrm{G}_{1}$ requires the coordinate action of both cyclin $\mathrm{D}$ and cyclin E kinases. The development of the hypertrophy of tubular cells was shown to occur in temporal association with increases in cyclin D/CDK4/6 kinase activities, and decreased activation of cyclin E/CDK2 complexes. Failure to activate the cyclin E/CDK2 complex could be the result of either a decrease in the formation of kinase complexes, or an increase in cyclin kinase inhibitor proteins associated with these complexes [15]. The cyclin kinase inhibitor proteins of the Cip/kip family, which include $\mathrm{p} 21^{\text {Waf1 }}$, p2 $7^{\mathrm{kip} 1}$ and $\mathrm{p} 57^{\mathrm{kip} 2}$, play an essential role in hypertrophy, because they inhibit activity of early $G_{1}$ (cyclin $D /$ CDK4/6), late $\mathrm{G}_{1}$ (cyclin E/CDK2), and S-phase (cyclin A/ CDK2) cyclin-CDK complexes [16, 17]. Studies showed that the levels of cyclins and CDKs remain constant, while the activity of formed complexes change during the compensatory growth period. Activity of the cyclin D/ CDK4/6 complexes increases at days 4, 7, and 10, and activity of the cyclin E/CDK2 increases at days 2, 4, and 7-14 after nephrectomy in the remaining kidney tissues. Thus it is conceivable that $\mathrm{p} 21^{\text {Waf1 }}, \mathrm{p} 27^{\mathrm{kip} 1}$ and $\mathrm{p} 57^{\mathrm{kip} 2}$ may play essential roles in compensatory tubular cell hypertrophy [18-20].

\section{Role of Transforming Growth Factor- $\beta$ in Compensatory Renal Growth}

Transforming growth factor- $\beta$ (TGF- $\beta$ ) is a multifunctional growth factor that mediates normal cell functions and many of the pathologic changes associated with a variety of kidney diseases. These include regulation of cell proliferation, accumulation of extracellular matrix, glomerular and interstitial fibrosis, and the progression of glomerulosclerosis [21-24]. TGF- $\beta$ was described as inducer of epithelial-to-mesenchymal transition in normal mammary epithelial cells, by the activation of a signaling pathway through serine/threonine kinase receptor complexes [25]. In addition, TGF- $\beta$ has been suggested as one of the most important factors causing tubular cell hypertrophy. TGF- $\beta$ is therefore considered to play a pivotal role in compensatory renal growth [26-29]. TGF$\beta$ induces hypertrophy of tubular cells through a cell cycle-dependent mechanism that involves entry of cells into the $G_{1}$ phase, initiating $G_{1}$-related events, and arresting cell cycle progression prior to the $G_{1} / S$ restriction point $[26,30,31]$. Moreover, moving cells from $G_{0}$ to $G_{1}$ and induction of early $\mathrm{G}_{1}$-associated effects by promitogenic stimuli such as EGF, IGF-I, FGF, IL-10 and HGF is a nec- 
essary event, which is subsequently converted to hypertrophy by anti-proliferative effects of TGF- $\beta$ in late $\mathrm{G}_{1}$ $[26,30]$. TGF- $\beta$ mediates hypertrophy via inhibition of $\mathrm{pRb}$ phosphorylation by blocking the activity of cyclin E/ CDK2 complexes, but does not affect the activity of cyclin $\mathrm{D} / \mathrm{CDK} 4 / 6$ complexes $[18,26,31]$. In vivo and in vitro studies revealed that TGF- $\beta$-induced compensatory tubular cell hypertrophy is regulated by $\mathrm{p} 57^{\mathrm{kip} 2}$, but not by $\mathrm{p} 21^{\text {Waf1 }}$ or $\mathrm{p} 27^{\mathrm{kip} 1}$ cyclin kinase inhibitor proteins [32-34].

TGF- $\beta$ is synthesized and secreted by a variety of renal cells $[35,36]$. Generally, TGF- $\beta$ is stored as a disulfidebonded homodimer connected to a latency-associated protein (LAP). In this state, TGF- $\beta$ is maintained in its inactive, latent form. Binding of the cytokine to its receptor requires its activation, by dissociation from LAP. This process is induced by several factors, including cathepsins, plasmin, calpain, thrombospodin, integrin- $\alpha \mathrm{v} \beta 6$, and matrix metalloproteinases [37-39]. Most of these factors are produced by mesangial cells.

\section{How Do Mesangial Cells Influence Compensatory Tubular Cell Hypertrophy?}

Although the tubular cells are the main site at which compensatory renal growth takes place, it has been suggested that mesangial cells play an essential role in this process.

Glomerular mesangial cells play an important role in maintaining normal glomerular structure and function [5, 40-42]. Recent studies of renal tissues and isolated glomeruli showed that mesangial cells serve as both the source and the target for various growth factors, cytokines, and chemokines active in this tissue [6, 41-44]. These factors activate mesangial cells in an autocrine manner and mediate interactions with glomerular endothelial and epithelial cells, and with blood-borne inflammatory cells $[6,42]$. Generally, mesangial cell proliferation is tightly regulated by the combined activity of paracrine and autocrine growth factors. Activation and/or proliferation of the mesangial cells in response to immune-mediated or non-immune injury is followed by an imbalance in the production of growth factors, cytokines and extracellular matrix proteins, leading to glomerular and interstitial damage in the setting of diabetes, hypertension, or glomerulonephritis [42-47].

Studies from our group showed that in adult rats, unilateral nephrectomy first initiates significant transient proliferation of the mesangial cells [34]. At this stage, the levels of circulating expression of growth factors and cy- tokines, and of those expressed on the kidney tissue, such as growth hormone, IGF-I, IL-10, and others are markedly increased, leading to mesangial cell proliferation [29, 48-50]. On the other hand, concentrations of anti-proliferative mesangial cell factors, such as atrial natriuretic peptide and TGF- $\beta$, are greatly reduced relative to their baseline levels in both serum and in the remaining kidney tissue [29, 51].

Mesangial cell proliferation initiated by unilateral nephrectomy reaches a maximum at $24 \mathrm{~h}$, and is then arrested within $72 \mathrm{~h}$ after surgery. Reduction in proliferation occurs in parallel with the appearance of renal tubular cell hypertrophy $[29,34]$.

It has been shown that cultured mesangial cells isolated from a remaining kidney secrete factor(s) that, in concert with serum obtained from unilateral nephrectomized rats, stimulates growth of cultured tubular cells [52]. As mentioned above, TGF- $\beta$ is considered to be a pivotal factor in the progression of compensatory renal growth of the remaining kidney. It has been demonstrated that among the resident renal cell types studied, only mesangial cells secrete and activate TGF- $\beta[53,54]$. Moreover, TGF- $\beta$ production is regulated by factors such as angiotensin II, IGF-I, HGF, bFGF, TNF- $\alpha$, EGF, PDGF, and others, all of which are produced by mesangial cells [55-58]. Another inducer of TGF- $\beta$ is IL-10. In vivo studies showed that the major source of IL-10 in kidneys is the mesangial cells [29]. Following unilateral nephrectomy, plasma levels of both IL-10 and TGF- $\beta$ are increased, and correlate positively with their expression in renal tissues. IL-10 expression in the remaining kidneys starts to increase within hours after surgery, reaches a maximum at $24 \mathrm{~h}$ and returns to normal levels by several days after nephrectomy. In contrast to IL-10, circulating and renal TGF- $\beta$ levels decrease within $24 \mathrm{~h}$ after nephrectomy, and then start rising from $72 \mathrm{~h}$, reaching a peak at 1 week after nephrectomy. Thus, upregulation of IL-10 in plasma and kidney tissues appears earlier than the increase in TGF- $\beta$. Experimental in vivo inhibition of IL-10 levels reduces circulating and renal TGF- $\beta$ concentrations. This results in a $20-25 \%$ reduction in the remaining kidney weight and significantly decreases tubular cell hypertrophy $[29,34]$. It is important to note that IL-10, an autocrine mesangial cell growth factor [44], apparently has no direct effect on tubular cells [59-61]. Moreover, insitu hybridization [62] and immunohistochemical studies [29] both demonstrated that IL-10 does not stain the tubular cells; thus the interaction between IL-10 and tubular cell hypertrophy is indirect, occurring through the mesangial cell population. 


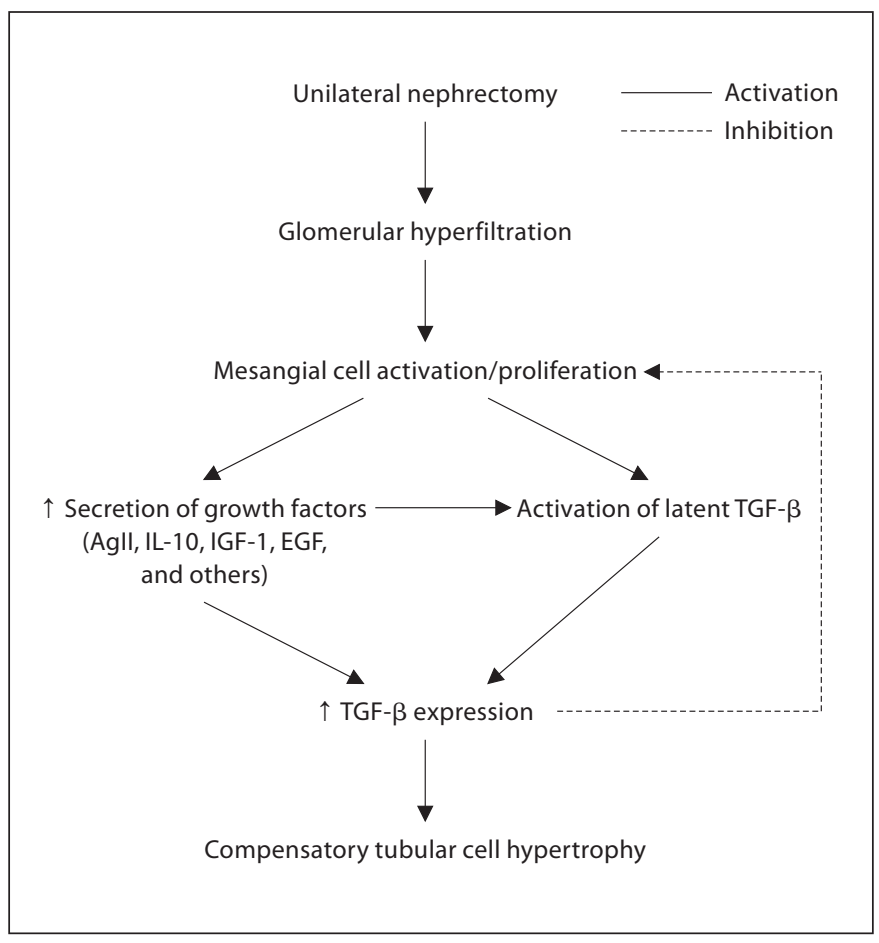

Fig. 1. Possible mechanisms involved in compensatory renal growth after unilateral nephrectomy.

Studies using inhibitors of IL-10 further emphasize the role of mesangial cells as the key regulator of the process of compensatory renal growth $[29,34]$. As summarized in figure 1, nephrectomy initiates glomerular hyperfiltration, which is followed by activation and proliferation of the mesangial cells in the remaining kidney. Proliferating mesangial cells produce increased amounts of growth factors. These growth factors effect mesangial cells in an autocrine manner to prolong activation, influence conversion of latent TGF- $\beta$ forms to active ones, and lead to increased TGF- $\beta$ production. When TGF- $\beta$ accu- mulates in sufficient amounts, it induces tubular cells to themselves undergo hypertrophy, and, in parallel, acts on the mesangial cells to inhibit their proliferation. Inhibition of mesangial cell proliferation, in turn, reduces TGF$\beta$ levels and inhibits compensatory tubular cell hypertrophy.

The mechanisms of renal hypertrophy in response to loss of renal mass are fundamental to understanding the biology of the kidney and the progression of renal failure. Tubular cell hypertrophy occurs in several pathological conditions including diabetes mellitus. Moreover, tubular cell hypertrophy occurring after unilateral nephrectomy and the hypertrophy associated with diabetes mellitus, both occur through a process involving cell cycledependent mechanisms $[8,63]$. The permanent and progressive loss of functioning nephrons following development of renal failure initiates a cascade of events, which are common to those in the renal compensatory growth process. Abnormal mesangial cell proliferation which is followed by generation of various growth factors, cytokines and matrix molecules in response to pathologic stimuli represent a common mechanism for the progression of a variety of renal disease leading to end-stage renal failure $[42,45,46]$. An increase in extracellular matrix deposition ultimately leads to induction of glomerular fibrosis and sclerosis, and results in the appearance and accumulation of proteinuria and a reduction in glomerular filtration rate due to loss of functioning nephrons [39, 50, 64-66]. In addition, increased secretion of chemokines by activated/proliferating mesangial cells is a necessary step contributing to inflammatory influx of leukocytes inducing proapoptotic and profibrotic lesions in the diseased kidney $[43,67]$.

This review summarizes our understanding of the mechanisms underlying the compensatory growth of the remaining kidney, which may shed light on the progression of renal diseases and identify potential targets for therapeutic intervention.

\section{References}

Mesangial Cells and Compensatory Renal Growth
1 Aristotle: Generation of animals (translated by Peck AL). Cambridge, Harvard University Press, 1942, p 429.

2 Rhodius J: Mantissa anatomica ad Thomam Bartholinium. Copenhagen, P Haubold, 1661. Referenced after Nowinsky WW: Early history of renal hypertrophy; in Nowinsky WW, Goss RJ (eds): Compensatory Renal Growth. New York, Academic Press, 1969, pp 1-8.

\footnotetext{
Wesson LG: Compensatory growth and other growth responses of the kidney. Nephron 1989;51:149-184.

4 Fine LG, Norman JT: Renal growth responses to acute and chronic injury: routes to therapeutic intervention. J Am Soc Nephrol 1992;2:S202-S211.

5 Stockand JD, Sansom SC: Glomerular mesangial cells: electrophysiology and regulation of contraction. Physiol Rev 1998; 78:
} 723-744. 
-6 Schena FP, Strippoli GF, Wankelmuth P: Renal growth factors: past, present and future. Am J Nephrol 1999;19:308-312.

7 Moskowitz DW, Liu W: Gene expression after unilateral nephrectomy in the rat: simultaneous expression of positive and negative growth control elements. J Urol 1995;154: 1560-1565.

$\checkmark 8$ Liu B, Preisig PA: Compensatory renal tubular hypertrophy is mediated by a cell cycledependent mechanism. Kidney Int 2002;62: 1650-1657.

-9 Shankland SJ: Cell cycle regulatory proteins in glomerular disease. Kidney Int 1999;56: 1208-1215.

10 Wolf G: Molecular mechanisms of renal hypertrophy: role of p27kip1. Kidney Int 1999; 56:1262-1265.

$\checkmark 11$ Kitagawa M, Higashi H, Jung HK: The consensus motif for phosphorylation by cyclin D1-cdk4 is different from that for phosphorylation by cyclinA/E-cdk2. EMBO J 1996;15: 7060-7069.

-12 Connell-Crowley L, Harper JW, Goodrich DW: Cyclin D/cdk4 regulates retinoblastoma protein-mediated cell cycle arrest by sitespecific phosphorylation. Mol Biol Cell 1997; 8:287-301.

$\checkmark 13$ Lundberg AS, Weinberg RA: Functional inactivation of the retinoblastoma protein requires sequential modification by at least two distinct cyclin-cdk complexes. Mol Cell Biol 1998;18:753-761.

-14 Ezhevsky SA, Nagahara H, Vocero-Akbani AM, Glus DR, Wel MC, Dowdy SF: Hypophosphorylation of the retinoblastoma protein (pRB) by cyclin D-cdk 4,6 complexes results in active pRB. Proc Natl Acad Sci USA 1997;94:10699-10704.

$\checkmark 15$ Morgan DO: Principles of CDK regulation. Nature 1995;374:131-134.

-16 Shankland SJ, Pippin J, Flanagan M, Coats SR, Nangaku M, Gordon KL, Roberts JM, Couser WG, Johnson RJ: Mesangial cell proliferation mediated by PDGF and bFGF is determined by levels of the cyclin kinase inhibitor p27kip1. Kidney Int 1997;51:1088-1099.

-17 Wolf G, Nelson EG: Molecular mechanisms of tubulointerstitial hypertrophy and hyperplasia. Kidney Int 1991;39:401-420.

18 Liu B, Preisig PA: TGF- $\beta$-mediated hypertrophy in rat renal epithelial cells involves inhibiting phosphorylation by preventing activation of cdk2/cyclin E kinase. Am J Physiol 1999;277:F186-F194.

19 Shankland SJ, Hamel PA, Scholey JW: Cyclin and cyclin dependent kinase expression in the remnant glomerulus. J Am Soc Nephrol 1996;8:368-375.

-20 Park SK, Kang SK, Lee DY, Kang MJ, Kim $\mathrm{SH}$, Kon GY: Temporal expression of cyclins and cyclin dependent kinases during renal development and compensatory growth. Kidney Int 1997;51:762-769.
21 Blobe GC, Schiemann WP, Lodish FH: Role of transforming growth factor $\beta$ in human disease. N Engl J Med 2000;342:1350-1358.

22 Bottinger EP: TGF- $\beta$ in renal injury and disease. Semin Nephrol 2007;27:309-320.

23 Chen S, Jim B, Ziyadeh FN: Diabetic nephropathy and transforming growth factorbeta: transforming our view of glomerulosclerosis and fibrosis build-up. Semin Nephrol 2003;23:532-543.

24 Liu Y: Renal fibrosis: new insights into the pathogenesis and therapeutics. Kidney Int 2005;69:213-217.

25 Heldin $\mathrm{CH}$, Landström M, Moustakas A: Mechanism of TGF-beta signaling to growth arrest, apoptosis, and epithelial-mesenchymal transition. Curr Opin Cell Biol 2009;21: 166-176.

26 Franch HA, Shay JW, Alpern RJ, Preisig PA: Involvment of $\mathrm{pRb}$ family in TGF- $\beta$ dependent epithelial cell hypertrophy. J Cell Biol 1995;129:245-254.

27 Fujita H, Omori S, Ishikura K, Hida M, Awazu M: ERK and p38 mediated high-glucoseinduced hypertrophy and TGF-beta expression in renal tubular cells. Am J Physiol Renal Physiol 2004;286:F120-F126.

$\checkmark 28$ Wolf G, Mueller E, Stahl RA, Ziyadeh FN: Angiotensin II-induced hypertrophy of cultured murine proximal tubular cells is mediated by endogenous transforming growth factor-beta. J Clin Invest 1993;92:1366-1372.

29 Sinuani I, Averbukh Z, Gitelman I, Rapoport MJ, Sandbank J, Albeck M, Sredni B, Weissgarten J: Mesangial cells initiate compensatory renal tubular hypertrophy via IL-10 induced TGF- $\beta$ secretion: effect of the immunomodulator AS101 on this process. Am J Physiol Renal Physiol 2006;291:F384-F394.

30 Franch HA, Curtis PV, Mitch WE: Mechanisms of renal tubular cell hypertrophy: mitogen-induced suppression of proteolysis. Am J Physiol 1997;273:C843-C851.

31 Nagahara H, Ezhevsky SA, Vocero-Akbani AM, Kaldis P, Solomon MJ, Dowdy SF: Transforming growth factor $\beta$ targeted inactivation of cyclin E: cyclin-dependent kinase 2 (Cdk2) complexes by inhibition of Cdk2 activating kinase activity. Proc Natl Acad Sci USA 1999;96:14961-14966.

32 Scandura JM, Boccuni P, Massaque J, Nieme SD: Transforming growth factor $\beta$-induced cell cycle arrest of hematopoietic cells requires p57kip2 up-regulation. Proc Natl Acad Sci USA 2004;101:15231-15236.

$\checkmark 33$ Chen Z, Li DQ, Tong L, Stewart P, Chu C, Pflugfelder SC: Targeted inhibition of p57 and p15 blocks transforming growth factor beta-inhibited proliferation of primary cultured human limbal epithelial cells. Mol Vis 2006;23:983-994.
34 Sinuani I, Weissgarten J, Beberashvili I, Rapoport MJ, Sandbank J, Feldman L, Albeck M, Averbukh Z, Sredni B: The cyclin kinase inhibitor p57kip2 regulates TGF-beta-induced compensatory tubular hypertrophy: effect of the immunomodulator AS101. Nephrol Dial Transplant 2009;24:23282338

>35 Massague J: The transforming growth factor- $\beta$ family. Annu Rev Cell Biol 1990;6:597631.

36 Han DC, Hoffman BB, Hong SW, Guo J, Ziyadeh FN: Therapy with antisense TGF-betal oligonucleotudes reduces kidney weight and matrix mRNAs in diabetic mice. Am J Physiol Renal Physiol 2000;278:F628-F634.

37 Gorelik L, Flavell RA: Transforming growth factor- $\beta$ in T-cell biology. Nat Rev Immunol 2002;2:46-53.

38 Morris DG, Huang X, Kaminski N, Wang Y, Shapiro SD, Dolganov G, Glick A, Sheppard D: Loss of integrin alpha(v)beta 6-mediated TGF-beta activation causes MMP 12-dependent emphysema. Nature 2003;13:422:130131

39 Wynn T: Cellular and molecular mechanisms of fibrosis. J Pathol 2008;214:199-210.

40 Latta H, Fligiel S: Mesangial fenestrations, sieving, filtration, and flow. Lab Invest 1985; 29:591-598

41 Ling BN, Matsunaga H, Ma H, Eaton DC: Role of growth factors in mesangial cell ion channel regulation. Kidney Int 1995;48: 1158-1166.

42 Schlöndorff D, Banas B: The mesangial cell revisited: no cell is an island. J Am Soc Nephrol 2009;20:1179-1187.

43 Banas B, Luckow B, Moller M, Kleir C, Nelson PJ, Schadde E, Brigl M, Halevy D, Holthofer L, Reinhart B, Schlondoff D: Chemokine and chemokine receptor expression in a novel mesangial cell line. J Am Soc Nephrol 1999;10:2314-2322.

44 Chadban SJ, Tesch GH, Foti R, Atkins RC, Nikolic-Paterson DJ: Interleukin-10 is a mesangial cell growth factor in vitro and in vivo. Lab Invest 1997;76:619-627.

45 Cove-Smith A, Hendry BM: The regulation of mesangial cell proliferation. Exp Nephrol 2008;108:74-79.

46 Schocklmann HO, Lang S, Sterzel RB: Regulation of mesangial cell proliferation. Kidney Int 1999;56:1199-1207.

-47 Choi ME, Kim EG, Huang Q, Ballermann BJ: Rat mesangial cell hypertrophy in response to transforming growth factor-beta 1 . Kidney Int 1993;44:948-958.

48 Flyvbjerg A, Bennett WF, Rasch R, van Neck JW, Groffen CA, Kopchick JJ, Scarlett JA: Compensatory renal growth in uninephrectomized adult mice is growth hormone dependent. Kidney Int 1999;56:2048-2052. 
49 Mulroney SE, Scikos T, Koenig JI, Pesce C, Striker L, LeRoith D, Haramati A: Temporal increases in renal IGF-1, c-fos, and c-jun gene expression during hyperplastic kidney growth in weanling rats. Endocrinology 1996;137:839-845.

50 Johnson RJ: Cytokines, growth factors and renal injury: where do we go now? Kidney Int 1997;52(suppl 63):2-6.

- 51 Averbukh Z, Berman S, Weissgarten J, Cohn M, Golik A, Cohen N, Shaked U, Modai D: 1. Paradoxical effect of unilateral nephrectomy on serum atrial natriuretic peptide in rats. Ren Physiol Biochem 1994;17:101-107.

- 52 Averbukh Z, Berman S, Weissgarten J, Cohn M, Golik A, Cohen N, Modai D: Postnephrectomy mesangial cells secrete a factor(s) that stimulate(s) tubular cell growth in vitro. Nephron 1992;60:216-219.

- 53 Kaname S, Uchida S, Ogata E, Kurokawa K: Autocrine secretion of TGF- $\beta$ in cultured rat mesangial cells. Kidney Int 1992;42:13191324.

- 54 Kitamura M, Suto Y, Yokoo T, Shimizu F, Fine LG: TGF- $\beta$ is the predominant paracrine inhibitor of macrophage cytokine synthesis produced by glomerular mesangial cells. J Immunol 1996;156:2964-2971.

- 55 Wolf G, Ziyadeh FN, Zahner G, Stahl RA: Angiotensin II-stimulated expression of transforming growth factor beta in renal proximal tubular cells: attenuation after stable transfection with the c-mas oncogene. Kidney Int 1995;48:1818-1827.
56 Song K, Cornelius SC, Reiss M, Danielpour D: Insulin-like growth factor-I inhibits transcriptional responses of transforming growth factor-beta by phosphatidylinositol 3-kinase/Akt-dependent suppression of the activation of Smad3 but not Smad2. J Biol Chem 2003;278:38342-38351.

57 Sullivan DE, Ferris M, Pociak D, Brody AR: The latent form of TGF-beta(1) is induced by TNFalpha through an ERK specific pathway and is activated by asbestos-derived reactive oxygen species in vitro and in vivo. J Immunotoxicol 2008;5:145-149.

58 Hardie WD, Davidson C, Ikegami M, Leikauf GD, Le Cras TD, Prestidge A, Whitsett JA, Korfhagen TR: EGF receptor tyrosine kinase inhibitors diminish transforming growth factor-alpha-induced pulmonary fibrosis. Am J Physiol Lung Cell Mol Physiol 2008;294:L1217-L1225.

59 de Waal Malefyt R, Abrams J, Bennett B, Figdor CG, de Vries JE: Interleukin 10 (IL-10) inhibits cytokine synthesis by human monocytes: an autoregulatory role of IL-10 produced by monocytes. J Exp Med 1991;174: 1209-1220.

-60 Gerritsma JS, Gerritsen AF, Van Kooten C, Van Es LA, Daha MR: Interleukin-1-alpha enhances the biosynthesis of complement C3 and factor $\mathrm{B}$ by human kidney proximal tubular epithelial cells in vitro. Mol Immunol 1996;33:847-854.
61 Riemann D, Kehlen A, Langner J: Stimulation of the expression and the enzyme activity of aminopeptidase N/CD13 and dipeptidylpeptidase IV/CD26 on human renal cell carcinoma cells and renal tubular epithelial cells by T cell-derived cytokines, such as IL-4 and IL-13. Clin Exp Immunol 1995; 100:277283.

62 Niemir ZI, Ondracek M, Dworacki G, Stein $\mathrm{H}$, Waldherr R, Ritz E, Otto HF: In situ upregulation of IL-10 reflects the activity of human glomerulonephritides. Am J Kidney Dis 1998;32:80-92.

63 Wolf G: Cell cycle regulation in diabetic nephropathy. Kidney Int Suppl 2000;77:S59S64.

64 Sterzel RB, Schulze-Lohoff E, Weber M, Goodman SL: Interactions between glomerular mesangial cells, cytokines and extracellular matrix. J Am Soc Nephrol 1992;2:S126S131.

-65 Kanwar YS, Wada J, Sun L, Xie P, Wallner EL, Chen S, Chugh S, Danesh FR: Diabetic nephropathy: mechanism of renal disease progression. Exp Biol Med 2008;233:4-11.

66 Schena FP, Gesualdo L: Pathogenetic mechanism of diabetic nephropathy. J Am Soc Nephrol 2005; 16:S30-S33.

67 Brown Z, Robson RL, Westwick J: Regulation and expression of chemokines: potential role in glomerulonephritis. J Leukoc Biol 1996;59:75-80. 